\title{
PENGANTAR RANCANGAN MODUL PELATIHAN MANAJEMEN WAKTU PADA HIMPUNAN MAHASISWA PROGRAM STUDI PSIKOLOGI UNIVERSITAS "X"
}

\author{
Linda \\ Program Studi Psikologi Universitas Bunda Mulia \\ linda@bundamulia.ac.id
}

\begin{abstract}
As an undergraduate, the activity of lectures and the organization becomes a learning event for working. Problem arises when they have difficulty regulating time between lectures and organizational activities. However, this can be overcome by developing time management skills through training as a form of intervention. The introduction to time management training module design is based on active training approach that uses the principles of experiential learning. At University " $X$ ", specifically at the program of study of Psychology, time management skills in the undergraduate association program measured using a scale of time management that consists of 15 item created by researcher with the range of validity 0,405-0,876 and reliability 0,889. The result is from 27 undergraduate, 17 have time management skills that tend to be low and 10 tend to be high. However the introduction to the design of training modules produced in this study has its limitation. It still needs further development on the next research in order to design a holistic training module of time management, which effectiveness can be tested more accurately.
\end{abstract}

Keywords: time management, training module, active training, experiential learning.

\begin{abstract}
ABSTRAK
Sebagai seorang mahasiswa, kegiatan perkuliahan dan organisasi menjadi ajang pembelajaran sebagai modal kerja. Masalah muncul ketika terjadi kesulitan mengatur waktu dalam menjalani kegiatan perkuliahan dan organisasi. Hal ini dapat diatasi dengan mengembangkan keterampilan manajemen waktu melalui pelatihan sebagai salah satu bentuk intervensi. Pengantar rancangan modul pelatihan manajemen waktu dibuat berdasarkan pendekatan active training yang menggunakan prinsip experiential learning. Keterampilan manajemen waktu pada mahasiswa himpunan program studi psikologi Universitas " $X$ " diukur menggunakan skala manajemen waktu yang terdiri dari 15 aitem dan dibuat oleh peneliti dengan rentang validitas 0,405-0,876 dan reliabilitas 0,889 . Hasil yang diperoleh adalah sejumlah 17 mahasiswa memiliki keterampilan manajemen waktu yang cenderung rendah dan 10 mahasiswa cenderung tinggi. Pengantar rancangan modul pelatihan yang dihasilkan pada penelitian ini memiliki keterbatasan. Perlu dilakukan pengembangan lebih lanjut pada penelitian selanjutnya agar terbentuk modul pelatihan manajemen waktu seutuhnya yang dapat diuji efektivitasnya.
\end{abstract}

Kata kunci: manajemen waktu, modul pelatihan, active training, experiential learning.

\section{PENDAHULUAN \\ 1.1 Latar Belakang}

Berdasarkan penelitian Direktorat Jenderal Pendidikan Tinggi (2014), pada tahun 2000 sekitar 5 juta tenaga kerja pernah mengenyam pendidikan di perguruan tinggi dan pada tahun 2010 jumlah ini meningkat menjadi lebih dari 10 juta. Data tersebut menunjukkan masyarakat Indonesia semakin menyadari pentingnya menempuh pendidikan. Dalam menempuh pendidikan di perguruan tinggi, kehidupan mahasiswa tidak terbatas oleh kegiatan perkuliahan. Banyak kegiatan kemahasiswaan dan organisasi mahasiswa yang biasanya tersedia di perguruan tinggi. Mahasiswa berhak dan disarankan untuk mengikuti kegiatankegiatan tersebut. Pihak perguruan tinggi berharap mahasiswa dapat mengembangkan soft-skill mahasiswa sehingga tidak hanya memiliki prestasi akademik yang 
memuaskan, namun mahasiswa juga memiliki pengalaman berorganisasi.

Himpunan mahasiswa pada umumnya dimiliki oleh setiap program studi atau jurusan. Demikian halnya program studi Psikologi Universitas "X" yang juga memiliki himpunan mahasiswanya sendiri. Setiap bulan himpunan mahasiswa program studi Psikologi Universitas " $\mathrm{X}$ " memiliki kegiatan seperti menyelenggarakan seminar, pelatihan, kunjungan sosial, dan live in bagi mahasiswa baru.

Berdasarkan hasil wawancara kepada tiga orang mahasiswa yang tergabung dalam himpunan mahasiswa program studi Psikologi Universitas "X", diperoleh informasi bahwa kegiatan yang dilakukan setiap bulan tidak terlepas dari hambatan atau kesulitan. Permasalahan yang paling kuat dirasakan oleh mereka adalah pengaturan waktu antara kegiatan perkuliahan dengan kegiatan organisasi kemahasiswaan. Ketiga mahasiswa lebih mengutamakan kegiatan perkuliahan daripada kegiatan himpunan. Padahal saat ini himpunan mahasiswa program studi Universitas " $\mathrm{X}$ " sedang berusaha lebih menggalakan kegiatan-kegiatan kemahasiswaan agar peran himpunan lebih dikenal.

Jika dilihat dari sudut pandang program studi Psikologi Universitas "X", pihak prodi mendorong para mahasiswa agar dapat lulus tepat waktu empat tahun. Oleh karena itu mata kuliah semakin dipadatkan yang berdampak pada jumlah materi yang banyak, namun harus diselesaikan dalam jangka waktu yang relatif singkat. Tentu saja perkuliahan tidak hanya mempelajari materi di dalam kelas, dosen secara rutin memberikan tugas kepada mahasiswa baik berupa tugas tertulis maupun tugas praktek. Untuk mengerjakan tugas-tugas tersebut, mahasiswa banyak menggunakan waktu di luar jam perkuliahan sebagai waktu mengerjakan tugas baik secara mandiri maupun berkelompok.

Idealnya antara kegiatan perkuliahan dan kemahasiswaan dapat berjalan beriringan, salah satu cara untuk menanggulanginya adalah dengan melakukan manajemen waktu. Ojo dan
Olaniyan (2008), mengatakan bahwa manajemen waktu bukan tentang melakukan banyak hal dala satu hari. Manajemen waktu adalah tentang melakukan hal-hal yang lebih penting. Manajemen waktu adalah kemampuan untuk memutuskan apa yang paling penting dalam kehidupan baik di tempat kerja (dalam hal ini di perguruan tinggi), di rumah, dan bahkan dalam kehidupan pribadi. Macan, T. H. (1994, dalam Puspitasari, 2013) mengemukakan bahwa manajemen waktu adalah pengaturan diri dalam menggunakan waktu seefektif dan seefisien mungkin dengan melakukan perencanaan, penjadwalan, mempunyaikontrol atas waktu, selalu membuat prioritas menurut kepentingannya, serta keinginan untuk terorganisasi yang dapat dilihat dari perilaku seperti mengatur tempat kerja dan tidak menunda-nunda pekerjaan yang harus diselesaikan.

Memperkenalkan manajemen waktu kepada mahasiswa dapat meningkatkan efisiensi belajar dan memfasilitasi perkembangan karir di masa depan (Kirillov, A. V., et al, 2015). Keterampilan melakukan manajemen waktu merupakan hal yang dapat dipelajari oleh setiap orang, terutama mahasiswa. Chulanova (2012 dalam Kirillov, A. V., et al, 2015) menyatakan bahwa akan sangat berguna untuk melakukan pelatihan kelompok untuk merencanakan aktivitas pelajar. Pelatihan mengenai manajemen waktu dapat menjadi sarana pengembangan keterampilan tersebut. Sebuah pelatihan dapat digunakan jika telah melalui proses rancangan modul pelatihan. Proses tersebut dijabarkan dalam bentuk modul pelatihan dengan tujuan instruksional umum (TIU) dan tujuan instruksional khusus (TIK) yang akan mencakup area pembelajaran kognitif, afektif, dan konatif (ABC - Affective, Behavioral, dan Cognitive learning).

\subsection{Tujuan Penelitian}

Penelitian ini bertujuan untuk mendapatkan gambaran manajemen waktu pada mahasiswa himpunan program studi Psikologi di Universitas " $X$ " dan memperoleh pengantar rancangan modul pelatihan manajemen waktu. 


\section{TINJAUAN PUSTAKA \\ 2.1 Manajemen Waktu}

Macan, T. H. (1994, dalam Puspitasari, 2013) mengemukakan bahwa manajemen waktu adalah pengaturan diri dalam menggunakan waktu seefektif dan seefisien mungkin dengan melakukan perencanaan, penjadwalan, mempunyai kontrol atas waktu, selalu membuat prioritas menurut kepentingannya, serta keinginan untuk terorganisasi yang dapat dilihat dari perilaku seperti mengatur tempat kerja dan tidak menunda-nunda pekerjaan yang harus diselesaikan.

Macan, T. H. (1994, dalam Macan, T. H. et al, 2010) mengemukakan aspek-aspek dalam manajemen waktu:

a. Penetapan tujuan dan prioritas

Penetapan tujuan dan prioritas ini dikaitkan dengan apa yang ingin dicapai atau apa yang dibutuhkan untuk memperoleh dan membuat prioritas dari tugas yang penting untuk mencapai tujuan.

b. Teknik manajemen waktu

Di dalam aspek ini meliputi proses dari rencana yang dilakukan seperti membuat daftar dan perencanaan. Perencanaan membuat seseorang mampu melakukan pekerjaan secara terorganisir dan membuat pekerjaan dapat diselesaikan tepat waktu.

c. Preferensi terhadap pengorganisasian

Aspek ini mengacu pada kecenderungan umum seseorang untuk menerapkan keteraturan, baik dalam lingkungan pekerjaan maupun pendekatan terhadap tugas. Hal tersebut memudahkan penyelesaian pekerjaan sehingga tepat pada waktunya, tidak merusak jadwal kegiatan yang sudah disusun dan membantu tercapainya tujuan yang sudah ditetapkan.

Peddler dan Boydell (Dale, 2003 dalam Puspitasari, 2013) menyatakan bahwa tingkat efektivitas seseorang dalam melakukan manajemen waktu dipengaruhi oleh beberapa aspek sebagai berikut:

\section{a. Kesehatan}

Kondisi fisik maupun psikis mempengaruhi seseorang dalam mengarahkan aktivitas kehidupan.
Kondisi kesehatan yang baik akan mewujudkan keseimbangan pada diri individu sehingga akan mempermudah dalam melakukan penyesuaian diri dalam melakukan manajemen waktu.

b. Keterampilan atau keahlian

Terdapat beberapa keterampilan yang diperlukan dalam kehidupan. Individu tersebut dapat memutuskan untuk menjadi seseorang yang memiliki berbagai keahlian sekaligus atau menjadi orang yang melakukan suatu keahlian tertentu.

c. Aktivitas

Individu yang mampu mengembangkan aktivitas hidupnya dengan baik adalah individu yang memiliki kepekaan terhadap berbagai alternatif atau cara pandang dan memiliki imajinasi moral yang tinggi sehingga keputusankeputusan aktivitas mempertimbangkan dua hal sekaligus, yaitu yang memberi manfaat bagi dirinya dan orang lain.

Manajemen waktu juga dipengaruhi beberapa faktor lain, diantaranya:

a. Jenis kelamin

Berdasarkan penelitian Macan, T. H. (1990) manajemen waktu dapat dipengaruhi oleh jenis kelamin. Khatib (2014) menjelaskan bahwa perempuan memiliki kemampuan manajemen waktu yang lebih baik daripada laki-laki. Perempuan cenderung melakukan aktivitas berdasarkan prioritas utama dan melakukan sesuatu yang bermanfaat bagi dirinya sedangkan laki-laki cenderung menghabiskan waktu dengan melakukan kegiatan yang tidak berguna

b. Prestasi akademik

Prestasi akademik dapat dicapai dengan baik jika mahasiswa memiliki manajemen waktu yang baik (Puspitasari, 2013). Hasil penelitian Khatib (2014) juga menyatakan bahwa manajemen waktu merupakan prediktor yang signifikan untuk pencapaian prestasi akademik.

\subsection{Active Training}

Agar seseorang dapat mempelajari sesuatu dengan baik, maka mereka harus mendengarnya, melihatnya, 
mempertanyakannya, mendiskusikannya dengan teman sebaya, dan melakukannya. Metode active training dibuat untuk meningkatkan partisipasi, menghidupkan suasana belajar, memperdalam pemahaman, dan mendorong pengaplikasian (Silberman, M. \& Elaine Biech, 2015).

Program active training memiliki karakteristik adanya aktivitas, variasi, dan partisipasi. Secara spesifik terdapat delapan kualitas yang membuat active training berhasil, yaitu (Silberman, M. \& Elaine Biech, 2015):

1. Materi dengan level moderat

2. Keseimbangan pembelajaran antara affective, behavioral, dan cognitive (ABC Learning)

3. Variasi pendekatan pembelajaran

4. Kesempatan untuk partisipasi kelompok

5. Memanfaatkan pengalaman partisipan

6. Memanfaatkan konsep dan keterampilan yang telah dipelajari sebelumnya

7. Pemecahan masalah dalam kehidupan nyata

8. Membuat perencanaan masa depan

Berikut ini adalah langkah-langkah yang digunakan sebagai panduan umum dalam merancang program active training (Silberman, M. \& Elaine Biech, 2015):

1. Menentukan kebutuhan pelatihan dan partisipan (Training Need Analysis)

2. Menentukan tujuan pembelajaran secara umum

3. Menspesifikan objek pembelajaran

4. Merancang aktivitas pelatihan

5. Mengatur susunan aktivitas pelatihan secara sistematis mulai dari pembukaan sampai penutupan

6. Membuat rencana yang lebih detail

7. Merevisi detail rancangan

8. Mengevaluasi hasil keseluruhan

Experiential learning tidak hanya meningkatkan pemahaman konsep, tapi juga mengembangkan keterampilan. Experiential learning khususnya cocok digunakan untuk mencapai tujuan pelatihan affective dan behavioral. Experiential learning mendukung partisipan untuk mempraktekkan dan memproses keterampilan dan prosedur baru. Berikut ini terdapat enam pendekatan utama dari experiential learning (Silberman, M. \& Elaine Biech, 2015):

1. Role playing

2. Permainan dan simulasi

3. Observasi

4. Mentalimagery

5. Writingtask

6. Actionlearning

Mengevaluasi program pelatihan seringkali dilihat sebagai tahap akhir, namun pada kenyataannya saat inilah dimulainya proses rancangan dan pelaksanaan. Hal tersebut memungkinkan karena dari program pelatihan kita memperoleh data yang dapat digunakan untuk mengembangkan program pelatihan. Mayoritas trainer menggunakan empat level evaluasi program pelatihan dari Dr. Donald Kirkpatrick (2005 dalam Silberman, M. \& Elaine Biech, 2015):

1. Reaction

Sikap partisipan terhadap pelatihan seperti kepuasan terhadap keterlibatannya atau hal-hal yang telah dipelajari.

2. Learning

Pengetahuan dan keterampilan yang dipelajari seperti dapat menyebutkan latihan terbaik dalam mempelajari keterampilan baru dalam menghadapi pekerjaan.

3. Behavior

Perubahan dalam penerapan keterampilan yang dipelajari dan mempraktekkan dalam pekerjaannya.

4. Result

Hasil kuantitatif yang menggambarkan dampak pelatihan terhadap organisasi.

\section{METODE PENELITIAN}

Penelitian ini menggunakan metode kuantitatif deskriptif non eksperimental. Populasi dalam penelitian ini adalah mahasiswa aktif yang pernah dan sedang tergabung dengan himpunan program studi Psikologi Universitas "X". Pengambilan sampel dalam penelitian ini menggunakan teknik Purposive Sampling. Jumlah sampel dalam penelitian ini adalah 27 mahasiswa.

Pembuatan pengantar rancangan modul pelatihan dan pengumpulan data (kuesioner) disusun oleh peneliti berdasarkan teori dan aspek-aspek manajemen waktu dari Macan, 
T. H., (1994, dalam Macan, T. H. et al, 2010). Kuesioner ini menggunakan skala Likert yang terdiri dari pernyataanpernyataan favorable dan unfavorable. Uji coba dalam penelitian ini adalah uji coba terpakai dengan pertimbangan terbatasnya jumlah responden. Hasil uji coba terpakai dari aitem yang sahih langsung digunakan untuk menguji hipotesis.

Uji coba dilakukan kepada 27 mahasiswa Himpunan Program Studi Psikologi Universitas "X". Batasan uji korelasi antar aitem dengan skor aitem yang digunakan adalah 0,381. Jumlah aitem sebelum uji coba berjumlah 24 aitem dan setelah dilakukan uji coba aitem yang valid berjumlah 15 aitem yang tersebar dalam tiga aspek manajemen waktu, sedangkan yang gugur berjumlah 9 aitem. Validitas 15 aitem berada pada rentang $0,405-0,876$ dengan reliabilitas 0,889 .

\section{HASIL DAN PEMBAHASAN}

Berdasarkan data yang diperoleh, diketahui mayoritas subjek adalah perempuan $(74,1 \%)$, usia subjek rata-rata adalah 20 tahun $(40,7 \%)$, berada di semester empat dan delapan (37\%), dan memiliki IPK $2,76-3,50$ sebanyak 15 orang $(55,5 \%)$.

Berdasarkan hasil pengolahan data, diperoleh hasil mean empirik < mean hipotetik $(44,48<47,5)$ yang berarti keterampilan manajemen waktu mahasiswa Program Studi Psikologi Universitas " $\mathrm{X}$ " cenderung rendah. Jumlah mahasiswa dengan keterampilan manajemen waktu yang cenderung rendah berjumlah 17 orang $(62,96 \%)$ dan cenderung tinggi berjumlah 10 orang $(37,04 \%)$. Berdasarkan hasil uji Chisquare diperoleh data bahwa terdapat hubungan antara manajemen waktu dengan jenis kelamin $(0,018<0,05)$. Sedangkan antara manajemen waktu dengan usia, semester, dan IPK tidak terdapat hubungan $(\mathrm{p}>0,05)$.

Data di atas menggambarkan mayoritas mahasiswa memiliki kesulitan dalam mengatur waktu antara kegiatan perkuliahan dengan himpunan. Kesulitan tersebut tidak berkaitan dengan usia, semester, dan IPK mahasiswa, melainkan berhubungan dengan jenis kelamin. Hubungan tersebut sejalan dengan penelitian Macan, T. H. (1990) bahwa manajemen waktu dapat dipengaruhi oleh jenis kelamin. Khatib (2014) menjelaskan bahwa perempuan memiliki kemampuan manajemen waktu yang lebih baik daripada laki-laki.

Berdasarkan hasil pengolahan data di atas, perlunya intervensi untuk membantu mahasiswa meningkatkan keterampilan manajemen waktunya. Bentuk intervensi yang dibuat pada penelitian ini adalah sebuah pengantar rancangan pelatihan manajemen waktu. Pengantar rancangan pelatihan ini dibuat berdasarkan pendekatan Active Training menggunakan prinsip Experiential Learning. Hal ini dimaksudkan agar tercipta suasana pelatihan yang bersemangat dan mahasiswa dapat lebih menghayati modul-modul yang akan diberikan terutama karena penerapan $A B C$ Learning. $A B C$ Learning menitikberatkan pada pembelajaran yang menyentuh sisi affective, behavioral, dan cognitive. Penggunaan prinsip Experiential Learning memungkinkan mahasiswa untuk mengembangkan keterampilan baru, dalam hal ini adalah manajemen waktu.

Pengantar rancangan modul pelatihan manajemen waktu ini dimulai dengan menganalisa kebutuhan pelatihan menggunakan skala manajemen waktu. Kemudian dilanjutkan dengan menentukan pembelajaran secara umum dan menspesifikan objek pembelajaran. Maka dari itu dibuatlah tujuan instruksional umum dan khusus. Peneliti pun mengaplikasikan tujuan instruksional umum dan khusus ke dalam sebuah rundown pelatihan. Hal tersebut merupakan bentuk pengaturan aktivitas pelatihan secara sistematis mulai dari pembukaan sampai penutupan termasuk di dalamnya lembar kerja yang akan digunakan oleh mahasiswa. Di akhir sebuah pelatihan sebaiknya dilakukan evaluasi pelatihan sebagai cara untuk mengevaluasi hasil keseluruhan pelatihan. Hal tersebut dimaksudkan agar dari program pelatihan yang telah dibuat dapat diperoleh data yang digunakan untuk mengembangkan program pelatihan itu sendiri. 


\section{SIMPULAN DAN SARAN}

Berdasarkan pengolahan data diperoleh hasil keterampilan manajemen waktu pada mahasiswa himpunan Program Studi Psikologi Universitas " $\mathrm{X}$ " cenderung rendah dengan jumlah 17 mahasiswa dan cenderung tinggi dengan jumlah 10 mahasiswa. Bentuk intervensi yang dirancang untuk meningkatkan keterampilan manajemen waktu mahasiswa adalah pelatihan manajemen waktu. Pelatihan ini dirancang menggunakan pendekatan Active Training dengan menerapkan Experiential Learning.

Untuk penelitian selanjutnya perlu diteliti faktor-faktor yang mempengaruhi kecenderungan tinggi maupun rendahnya keterampilan manajemen waktu. Pada penelitian berikutnya juga perlu mengembangkan pengantar rancangan modul pelatihan manajemen waktu ini supaya dapat menjadi modul pelatihan seutuhnya. Modul pelatihan yang telah dikembangkan dapat diuji coba kepada mahasiswa himpunan program studi Psikologi Universitas " $\mathrm{X}$ " untuk mengetahui sejauh mana efektivitasnya.

Mahasiswa yang memiliki keterampilan manajemen waktu cenderung rendah dapat mengikuti pelatihan manajemen waktu sebagai sarana untuk mengembangkan keterampilan tersebut. Pihak program studi psikologi dapat menghimbau kepada mahasiswa untuk mengikuti kegiatan pelatihan manajemen waktu sebagai salah satu alternatif cara dalam mengembangkan keterampilan manajemen waktu.

\section{KETERBATASAN PENELITIAN}

Penelitian ini hanya menghasilkan outline modul pelatihan manajemen waktu untuk mahasiswa himpunan program studi psikologi Universitas " $\mathrm{X}$ ". Oleh karena itu masih diperlukan penelitian lebih lanjut sebagai langkah berikutnya untuk menyempurnakan outline ini menjadi modul pelatihan manajemen waktu mahasiswa himpunan program studi psikologi Universitas " $\mathrm{X}$ " yang seutuhnya.

\section{DAFTAR PUSTAKA}

Direktorat Jenderal Pendidikan Tinggi. (2014). Sistem Pendidikan Tinggi Indonesia: Seberapa Responsif terhadap Pasar Kerja?. http://documents.worldbank.org/curated/ en/987731468266684105/pdf/892220B RI00P120abor0Market0May02014.pdf

Forsyth, P. (2009). Jangan Sia-Siakan Waktumu. Yogyakarta: PT Garailmu.

Goodwin, C. James. (2010). Research in Psychology Methods and Design $6^{\text {th }}$ Edition. USA: John Wiley \& Sons, Inc.

Gravetter, Frederick J. \& Lori-Ann B. Forzano. (2012). Research Methods for the Behavioral Sciences $4^{\text {th }}$ Edition. Canada: Wadsworth, Cengage Learning.

Khatib, A. S. A. (2014). Time Management and Its Relation To Student's Stress, Gender and Academic Achievement Among Sample of Students at Al Ain University of Science Technology, AUE. International Journal of Business and Social Research (IJBSR), 4, 47-58.

Kirillov, Andrey V., Dina K. T., Mikhail V. V., \& Sergey A. M. (2015). Theory and Practice of Time-Manajement in Education. Journal of Canadian Center of Sience and Education. 11 (19), 195204.

Macan, T. H., Shahani, C., Dipboye, R., \& Phillips, A. P. (1990). College Students' Time Management: Correlations With Academic Performance And Stress. Journal of Eductional Psychology, 82 (4), 760-780.

Macan, T.H., Gibson, J., \& Cunningham, J. (2010). Will You Remember to Read This Article Later When You Have Time? The Relationship Between Prospective Memory and Time Management. Personality and Individual Differences, 48 (6), 725-730. 
Puspitasari, W. (2013). Hubungan antara Manajemen Waktu dan Dukungan Social dengan Prestasi Akademik Mahasiswa yang Bekerja. Emphaty Journal Fakultas Psikologi, 2, 1-17.

Silberman, Melvin L., Elaine Biech. (2015). Active Training: A Handbook of Techniques, Designs, Case Examples, and Tips. New Jersey: John Wiley \& Sons, Inc.

\section{LAMPIRAN}

\section{Tujuan Instruksional Umum dan Khusus Pelatihan Manajemen Waktu}

Sesi 0 Ice Breaking

Tujuan Instruksional Umum:

* Mencairkan suasana dan menciptakan keterbukaan dan keakraban antar peserta juga dengan fasilitator.

Tujuan Instruksional Khusus:

* Menumbuhkan emosi positif untuk terlibat aktif dalam mengikuti pelatihan

* Peserta dan fasilitator dapat lebih saling mengenal satu sama lain

Kegiatan:

* Games

Sesi 1 Tujuan dan Prioritas

Tujuan Instruksional Umum:

* Peserta memahami pengertian dan pentingnya tujuan (jangka panjang dan jangka pendek) dan prioritas

* Peserta memahami faktor-faktor yang mempengaruhi penentuan tujuan dan prioritas

* Peserta memahami cara menetapkan goal secara SMART dan membuat skala prioritas

Tujuan Instruksional Khusus:

* Peserta dapat menyadari dan menuliskan tujuan (jangka panjang dan jangka pendek) dalam kehidupan perkuliahan dan himpunan prodi

* Peserta dapat menuliskan faktor-faktor yang mempengaruhi tujuannya tersebut

* Peserta dapat menuliskan tujuan yang diinginkan secara SMART

* Peserta dapat menuliskan skala prioritas berdasarkan tujuan SMART
* Peserta dapat mengevaluasi tujuan dan prioritas yang telah dibuat dengan mempertimbangkan keselarasan dari faktor-faktor yang mempengaruhi

Kegiatan:

* Video klip

* Games

* Ceramah

* Tugas tertulis

* Diskusi kelompok

Sesi 2 Membuat Daftar Perencanaan

Tujuan Instruksional Umum:

* Peserta memahami pengertian dan peranan daftar perencanaan (jadwal)

* Peserta memahami cara membuat daftar perencanaan (jadwal)

Tujuan Instruksional Khusus:

* Peserta dapat menuliskan daftar perencanaan (jadwal) kegiatan perkuliahan dan himpunan prodi

* Peserta dapat mengevaluasi daftar perencanaan (jadwal) yang telah dibuat dengan mempertimbangkan tujuan dan prioritas yang dibuat sebelumnya

Kegiatan:

* Games

* Ceramah

* Tugas tertulis

* Diskusi kelompok

Sesi 3 Penerapan Keteraturan

Tujuan Instruksional Umum:

* Peserta memahami pengertian dan pentingnya penerapan keteraturan

* Peserta memahami faktor-faktor yang mempengaruhi penerapan keteraturan

* Peserta memahami cara membuat action plan

Tujuan Instruksional Khusus:

* Peserta dapat menyadari dan menuliskan hal-hal yang berkaitan dengan penerapan keteraturan dalam kehidupan perkuliahan dan himpunan prodi

* Peserta dapat menuliskan faktor-faktor dalam kehidupannya yang mempengaruhi penerapan keteraturan

* Peserta dapat membuat action plan untuk menerapkan daftar perencanaan dengan mempertimbangkan faktor-faktor yang mempengaruhi penerapan keteraturan

Kegiatan: 
* Video klip

* Ceramah

* Diskusi kelompok

* Games

* Tugas tertulis

Sesi 4 Evaluasi dan Penutupan

Tujuan Instruksional Umum:

* Memperoleh data dan feedback dari peserta mengenai pelatihan yang sudah berlangsung

Tujuan Instruksional Khusus:
* Post-test bertujuan untuk menjaring data peserta setelah pelatihan untuk kemudian hasilnya dibandingkan dengan pre-test

* Evaluasi pelatihan secara keseluruhan bertujuan untuk menjaring data peserta mengenai program pelatihan yang telah berlangsung

* Doa penutup sebagai ucapan syukur dan pengucapan terimakasih kepada peserta dan pihak-pihak yang berpartisipasi

Kegiatan:

* Mengisi kuesioner 